\title{
THE STUDY OF THE PECULIARITIES OF THE TRANSPORT SYSTEM OF ODESSA HILLS. ODESSA FUNICULARS
}

\author{
${ }^{1}$ Storozhuk S.S., Ph.D, Associate Professor, \\ mesvet@ukr.net, ORCID: 0000-0001-8390-7190 \\ ${ }^{1}$ Dubinina N.V., Ph.D, Senior lecturer, \\ naty.dubinina83@ukr.net, ORCID: 0000-0002-3250-9528 \\ ${ }^{1}$ Odessa State Academy of Civil Engineering and Architecture \\ Didrikhsona str. 4, Odessa, 65029, Ukraine
}

\begin{abstract}
The off-street transport system of a mountainous relief is learnt in the article. The basic kinds of underground and ground transport, intended for the transportation of people and auxiliary cargoes in the conditions of a complex locality relief or the presence of water obstacles were identified: conveyor, lifting, rail, mono-rail, self-propelled. The advantages of the use of suspended and mono-rail cableways were found: functionality, profitability, manufacturability, comfort and safety.

The peculiarities of the Northern-Western Black Sea shore - precipitous banks of the Odessa Bay - the hills that are a recreational zone and the most popular places for the rest of local inhabitants and quests of the Black Sea shore were studied.

Despite the fact that the Odessa hills don't have a complex and a steep locality relief, on the hills the transport system, in the conditions of a complex relief, consisting of the cableways, funiculars, an escalator, a tunnel, bridges and lifts that became the Odessa's sightseeing was created that makes the Odessa coast more attractive for the development of the regional and the international tourism.
\end{abstract}

Keywords: a complex locality relief, a transport system, Odessa hills, cableways, a funicular.

The introduction. The relief has a very important and sometimes decisive meaning, when designing populated places and individual plots of their territories. The wrong use of the relief's peculiarities leads to the complication of the designing decisions, the rise in price of building works, and to the creation, in some cases, unfavorable conditions for buildings arrangement, the elements of the improvement, and the organization of traffic and pedestrians' movement. Therefore, a through studying of natural factors of a relief, namely its relief, influencing the selection of the projecting decisions must precede the acceptation of these or those planning decisions.

The main peculiarity of the Northern-Western Black Sea shore are the precipitous banks of the Odessa Bay - hills that are the sloping plots of the Earth surface, formed in the result of the relief forming processes, ongoing on the land and on the bottom of the Black Sea. The Odessa hills are a recreational zone and the most popular places for the rest of local inhabitants and quests of the Black Sea shore. On the upper edge of a plateau there are the rest houses, and on the lower one there are many natural and artificial beaches.

The Odessa slopes don't have a complicated and a steep locality relief, despite this, the overcome of steep rises and descents on a big distance is rather complicated for many groups of population. For this, on the Odessa hills during the centuries the off-street traffic was being used (funiculars, a cableway, an escalator).

The analysis of the latest studies and publications. The city's transport system is one of the most important city forming systems in city building, including all kinds of information, transport means, technical devices and structures on the ways of information. It provides the process of moving people and cargoes of a different purpose from one place to another, therefore, many scientific organizations and scientists study the transport system. In the given scientific work, the 
transport system in the conditions of a complicated relief of a (mountainous relief) for people moving on the recreational-touristic territories was studied. Therefore, the theoretical base of the article composes the studies of A. Prohorov; the scientific works of such scientists as, A. Korotkiy, A. Lagerev, B. Meshi, I. Lagerev, A. Panfilov "The development of the transport infrastructure of big cities and territories on the bases of the cableway technologies"; the bases of an industrial transport system "The transport systems and complexes of coal mines" are used.

The basic emphasis of the scientific paper was made on the study of the relief's peculiarities of the Odessa coast, and also the historical analysis of the transport system development of the Odessa hills was made. The given problem is studied by the Odessa scientists and organizations, such as "The Odessa State Academy of Civil Engineering and Architecture", "The Odessa National University after I.I. Mechnikov", etc. Also a great attention to this problem is given by the Odessa journalists, such as: A. Velmozhko, A. Dedulina, A. Ignatieva, Д. Kornishev, etc.

The problem setting. The transport system is one of the most important problems of a modern city and determines an active position of the state in the creation of the conditions for socialeconomical, innovative and ecological direction of the transport industry development. The transport system plays an enormous role in the development of the regional and the international tourism. Therefore, the analysis and the improvement of a transport network is the main problem for the conservation of a cultural meaning of historical cities, and the rise of their touristic attraction.

The purpose of the article is the studying and the analysis of the transport system of the Odessa slopes peculiarities, including the history of the Odessa funiculars.

The methodic of the investigation. The transport system in the conditions of a complicated (mountainous) relief was studied; the basic kinds of the transport system and its advantages are identified. The peculiarities of the Odessa coast terrain are determined. The historical analysis of the transport system of Odessa hills development was made.

\section{The basic material and its results.}

The transport system of a mountainous locality is the ordered managed complex of the interconnected transport devices, intended for moving people and auxiliary cargoes in the conditions of a complicated relief or the presence of water obstacles. The complexes of the underground and ground transport, such as conveyor, rail, cable, etc. compose the transport system (Table 1, Fig. 1) [1, 2].

Table 1 - The kinds of transport

\begin{tabular}{|c|c|c|}
\hline № & A kind of transport & The constructive varieties of transport kinds \\
\hline \multirow{2}{*}{1} & \multirow{2}{*}{ Conveyor } & Ribbon conveyors \\
\hline & & An escalator - a sloping plate conveyor \\
\hline \multirow[b]{2}{*}{2} & \multirow[b]{2}{*}{ Lift } & A lift - a stationary vertical loader \\
\hline & & $\begin{array}{l}\text { An elevator - a machine of a non-stop action in a } \\
\text { vertical or a sloping direction }\end{array}$ \\
\hline \multirow{3}{*}{3} & \multirow{3}{*}{ Rail } & Electric locomotives, diesel locomotives \\
\hline & & Cable transport \\
\hline & & A funicular - ground cableways \\
\hline \multirow{2}{*}{4} & \multirow{2}{*}{$\begin{array}{l}\text { Cable suspended transport } \\
\text { (Cableways) }\end{array}$} & Mono-cable suspended roads \\
\hline & & Two-cable suspended roads \\
\hline \multirow[t]{2}{*}{5} & \multirow[t]{2}{*}{ Mono-rail } & $\begin{array}{l}\text { Mono-rail roads with a cable traction - ground } \\
\text { mono-rail transport }\end{array}$ \\
\hline & & Metropolitan - underground mono-rail transport \\
\hline 6 & Self-propelled carriages & Trolleys - cargo-passengers self-propelled carriages \\
\hline
\end{tabular}

Today suspended and mono-rail cableways are actively being used in Canada, the USA, Germany, Austria, France, and many other countries for the movement of passengers as within big mega-cities, as within the touristic, recreational and natural territories. The investment and exploitation expenses on the building of cableways is twice less than when using the automobile

Bulletin of Odessa State Academy of Civil Engineering and Architecture, 2021, no. 82, page 9-18 
transport. Cable ways don't depend on the complexity of a relief and allow to connect the passenger or cargo-passenger terminals by the shortest distance, easily passing above the densely-populated districts, above water and other obstacles, allow to unload the city's auto highways and provide a high comfort level, and are also one of the safe kinds of transport.

Nowadays the use of the passenger cable transport isn't limited by its use only as a cableway, i.e. for the passengers' delivery from one point to another. Cable technologies have made the enormous step forward, having stood in one line with the other kinds of the passengers' public transport in the urbanized environment that opens new perspectives of its use as the city passenger transport - a cableway underground. From the view of economical activity, the passenger suspended cableways refer to the transport systems that are used as public passenger transport, and also for the movement of people on the recreational-touristic territories [3].

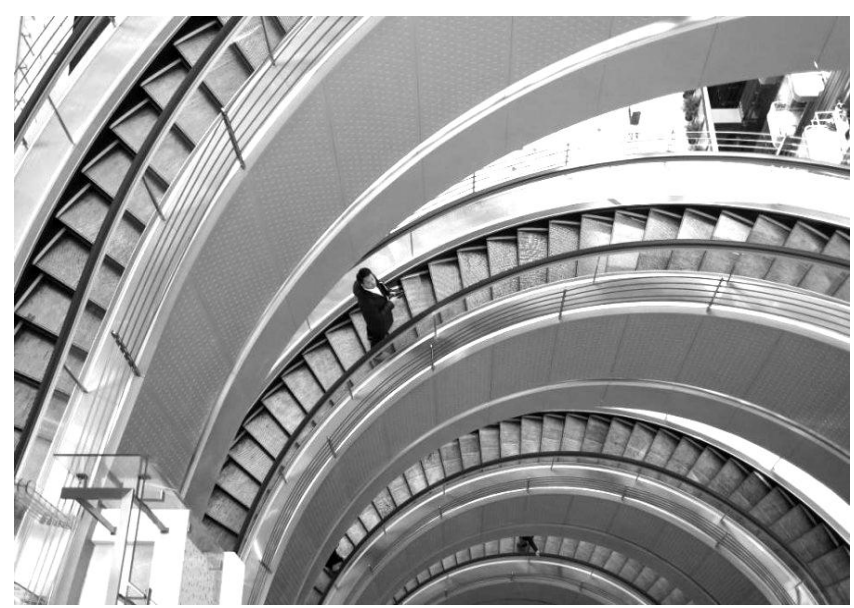

a) The spiral escalator in the department store New World Daimaru. Shanghai. China [4]

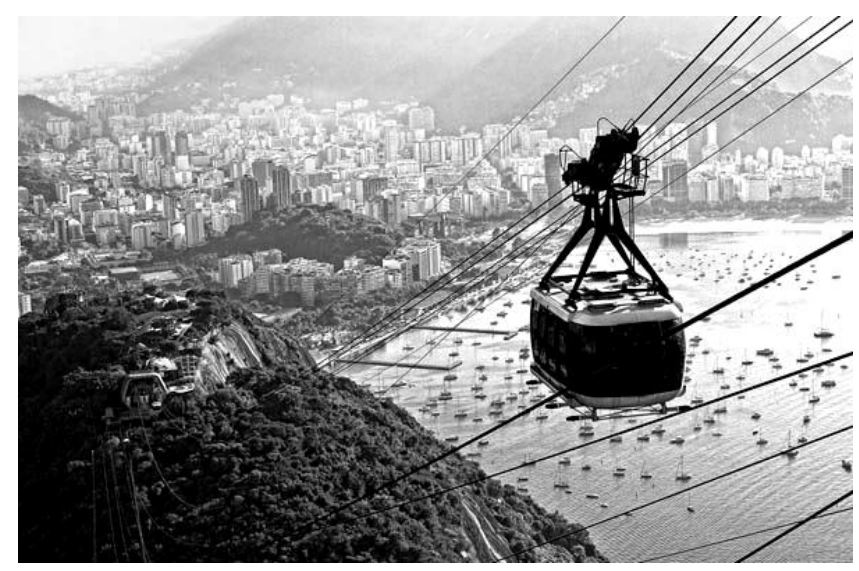

c) The cableway Complexo do Alemao, Brazil [6]



b) The funicular "Shtoos" (Stoosbahn).

Switherland [5]

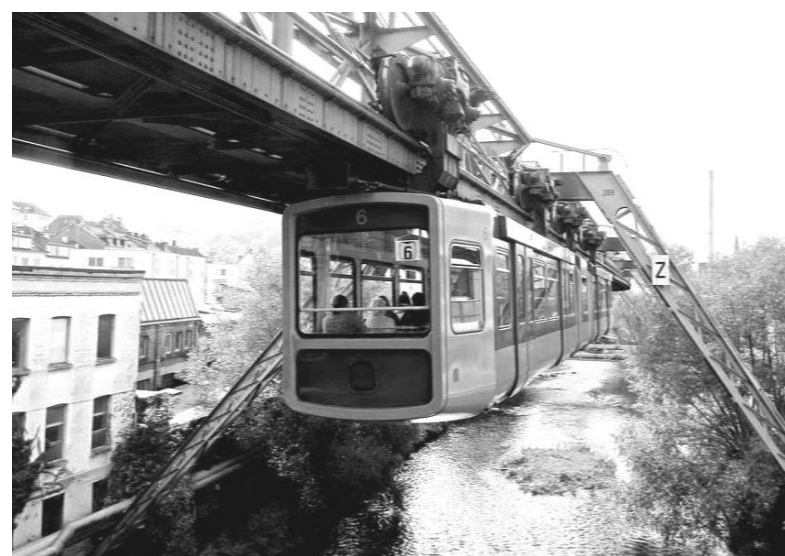

d) A mono-rail road of a suspended type in Wuppertal. Germany [7]

Fig. 1. The kinds of transport

The off-street transport of Odessa. The funiculars. The Odessa hills are a recreational zone and stretch along the entire Odessa coast, beginning from the central part of the city and up to the $16^{\text {th }}$ station of the Big Fountain. The access to the Odessa beaches from the upper plateau is done with the help of the extent stairs, lifts, a cableway and a funicular.

One of the main attractions of Odessa is the Potemkin Stairs, located in the central historical areal of the city, leading to the sea. From the upper steps of the Potemkin stairs of Primorsky Boulevard opens a wide panorama of the Sea Port, the harbor and the Odessa Bay. From the right side of it lies a famous Odessa funicular, not less popular in Odessa. 
The Odessa funicular refers to the three different systems of public transport and has a rich history. The $1^{\text {st }}$ funicular was built yet in the XX century $(1902-1969)$ and is called a lifting machine. The building of the funicular became the necessity for the city, when a number of people going to the Odessa Port and to Primorskaya Street considerably increased in connection with the opening of the railway report from the Port on the Kuyalnitskiy Estuary. The $1^{\text {st }}$ attempt to design the system of a railway lifting way from the pier on the Boulevard was undertaken in 1880, but remained incomplete. In 1895 the graduate of the Petersburg Institute of engineering ways of the report N. K. Pyatnitskiy presented his projecting decision of a mechanical lifting way, in the result of which the city's authorities declared the competition for the funicular's erection. Only the Parisian firm dared to compete with Pyatnitskiy, but the sketch project, presented by it, wasn't connected with the locality, and according to the conclusion of the city's famous engineer V.I. Zuev, the preference was given to Pyatnitskiy.

In 1900 - 1902 years the Odessa funicular with Parisian carriages, each for 35 passengers with the crossing bridge under it and a wooden openwork pavilion on the Boulevard was erected. The works were fulfilled under the supervision of the engineer V.Ya. Rakovskiy. The solemn opening of the lifting road took place on June, 8 1902, his work continued up to the complete closing in 1969. The Civil Revolution and the Great Patriotic War interrupted the work of the funicular from 1919 to 1926, and from 1942 to 1948, the funicular was "on the conservation" (Fig. 2).

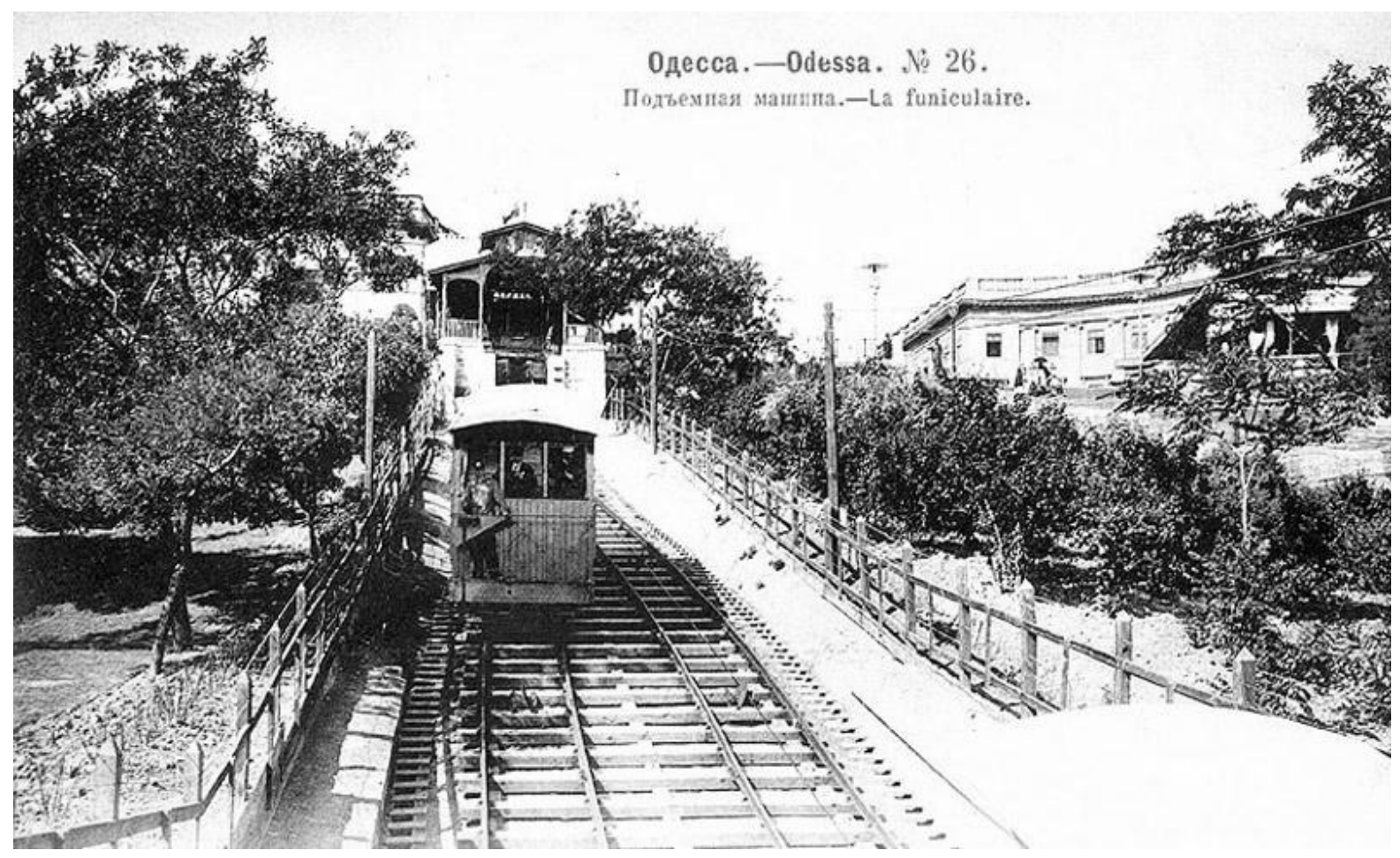

Fig. 2. The Odessa Funicular (1902 - 1969) [8]

In 1970 the funicular was replaced by the escalator that had worked for 30 years. In 1900 the escalator worked only to one way - on the rise, and the escalator on the descent was eventually taken apart for the spare parts. In 1997 the escalator was completely closed (Fig. 3, a).

In 1998 the city's authorities decided to restore the historical justice and recreate the Odessa funicular, the building works have continued for 8 years and in 2005 on September, 2 on the day of Odessa's birthday the solemn opening of the revived funicular, which acted as the sloping lifts (Fig. 3, b) [9].

The Monastic funicular. Except the famous funicular on Primorskiy Boulevard in Odessa was one more funicular - "monastic" on the Big Fountain. Its history is closely connected with the history of Svyato-Uspenskiy Patriarshiy Men's Monastery on the 16-th station of the Big Fountain. 


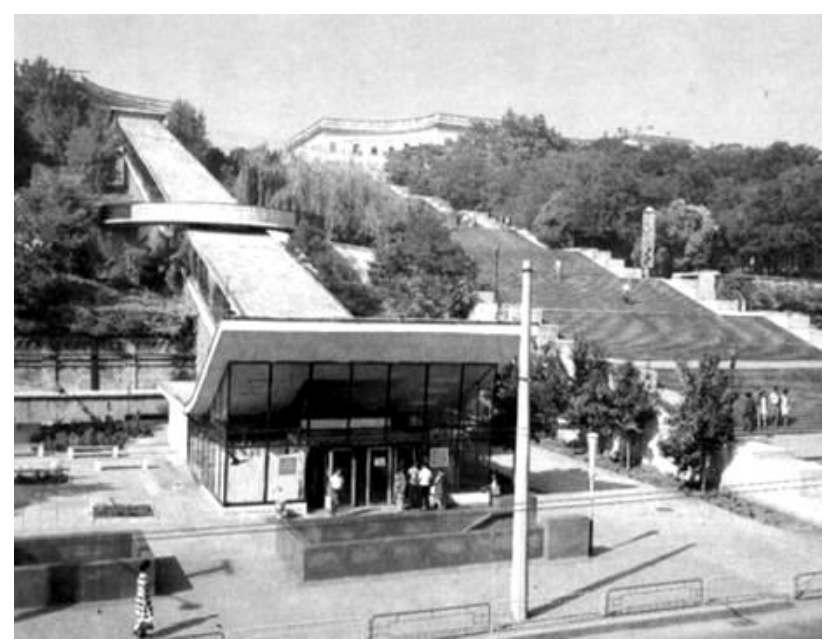

a)

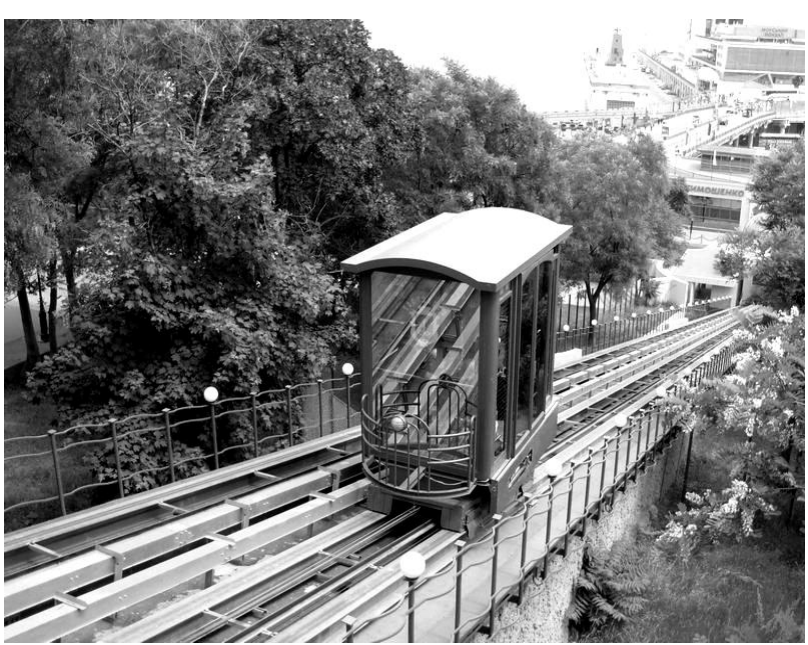

b)

Fig. 3. The Odessa Funiculars:

a - The Odessa Escalator (1970 - 1997) [10]; b - The Odessa Funicular (2005 - present time) [11]

Initially, it was the territory, belonging to the Moldavian landowner Alexandr Teutulu, who, afterwards, gave it to the church. Later, the Uspenskiy Monastery and the $1^{\text {st }}$ Odessa lighthouse, that hasn't survived to our days, appeared there.

In the 1950s a funicular for the delivery of high-ranking guests to the sea (now Popovskiy beach) and to the bathhouse was erected on the territory of the Monastery. Also for the Patriarch Moscovskiy and of all Russia Alexiy I (Simanskiy), who got the residence in Odessa on the cape the Big Fountain from the state - the building from the former Archiereyskiy House of the SvyatoUspenskiy Monastery for his health strengthening.

The funicular's line passed along the "hole", cut down in the lime break at an angle more than 45 degrees, and consisted of a one way and a small carriage with a cabin. The funicular worked correctly to 1970 , and was completely destroyed because of the repeated landslide in 1980s. Then began the building of the shore strengthening structures - near the cape of the Big Fountain the concrete piers were built, having shielded a small artificial harbour for borderline boats and fishing boats. The ancient wooden structures - The Patriach's Bathhouses on piles in water were destroyed in the late 1980s, after the building of concrete groins and replaced the funicular by the stairs (Fig. 4) [12, 13].

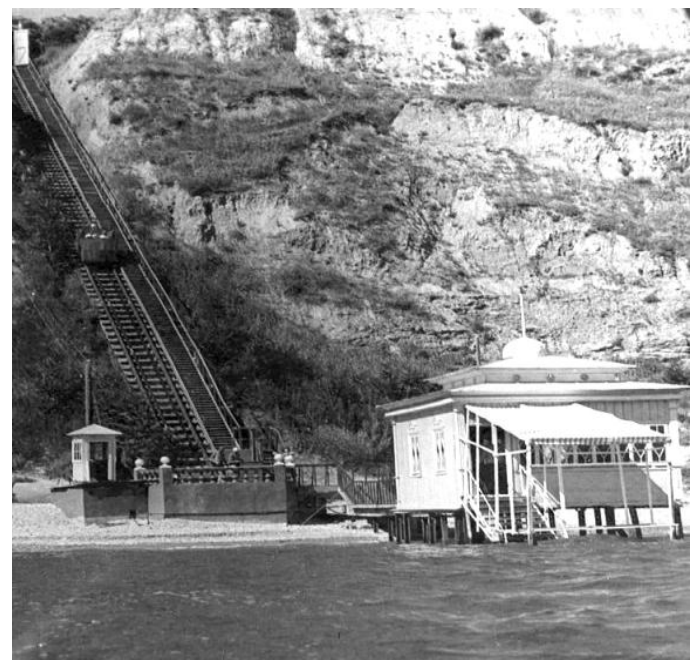

a)

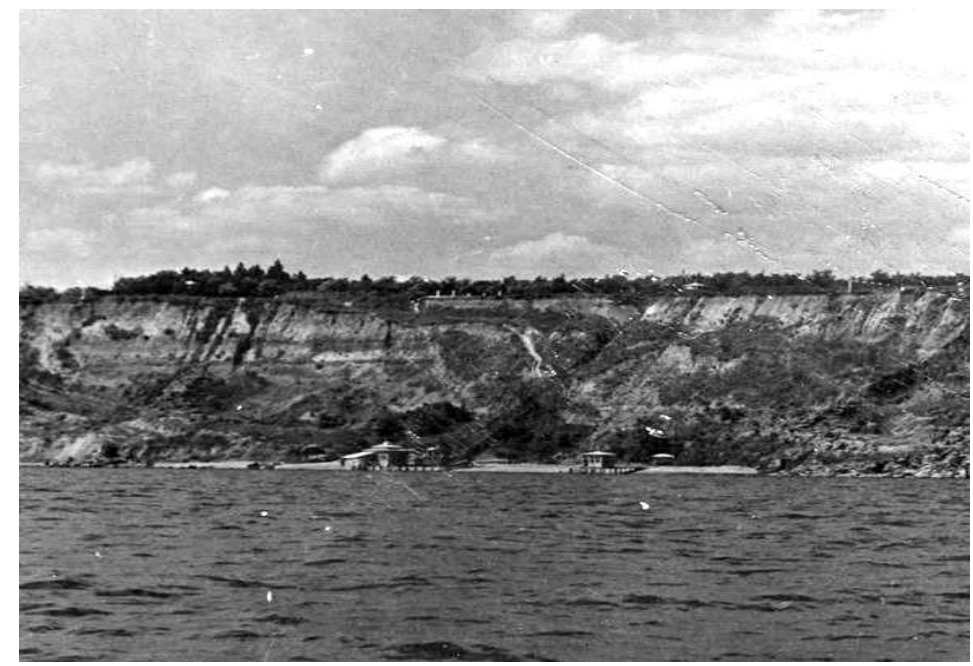

b)

Fig. 4. The Monastic funicular (1950-1980):

$a-$ General view of the funicular; $b$ - View of the funicular from the sea $[12,13]$ 
The cableway. Odessa is situated on the hill about 50-m above the sea level, along the sea coast lie healthy rest-houses and sanatoria. On the Odessa hills there are parks, where there is no traffic, therefore, one can reach the beach, and go back only on foot that poses the problem for a great number of tourists, especially in summer season.

In order to solve this problem, in 1971 the Odessa cableway was built, which became one of the leading attractions of the city, moreover, in Ukraine there are two cableways, the second one is located in Kharkiv.

The cableway in Odessa allows to overcome the height's drop of 37 meters quickly (only for $5 \mathrm{~min}$ ), and to descend from the French Boulevard to the coast, to the beach "Otrada", its length is 425 meters. The district of Otrada is located in the historical area of the city, and has a rich history and ancient architecture. Therefore, descending on the cableway, you can not only enjoy the picturesque landscapes of the Odessa Bay, but also the views of the local landscapes, also "The path of health", which stretches from the Shevchenko Park to Arcadia and is the most favorite place of bikers and walkers.

With time the Odessa hills were equipped with more qualitative walking ascents and descents to the sea, therefore, the cableway turned into the touristic attraction, but didn't lose its actuality. (Fig. 5, a) [14].

The fabulous tunnel. Odessa was always famous for its multiprofile heath resorts, sanatoria, that provided people with all kinds of sanatoria treatment and comfortable rest. That's why, in the sanatorium «Magnoliya» from 1976-to 1979 two lifts and the passenger tunnel from them to the beach were built, its length is $200 \mathrm{M}$, and the depth is about $20 \mathrm{M}$. The passenger tunnel links the $7^{\text {th }}$ body of the sanatorium "Magnoliya" on the French Boulevard, and the beach "The dolphin". For the defense from the mold the tunnel was lined by mosaics and stucco based on Pushkin's fairy-tales' motives, and above the entrance the quote of A. Chehov was placed: "The sea is wonderful, blue and delicate. The bathing got to that I plunged, and started laughing without any reason". Fabulous motives and colorful backlight of the vaults give the tunnel a wonderful view and attract tourists (Fig. 5, b).

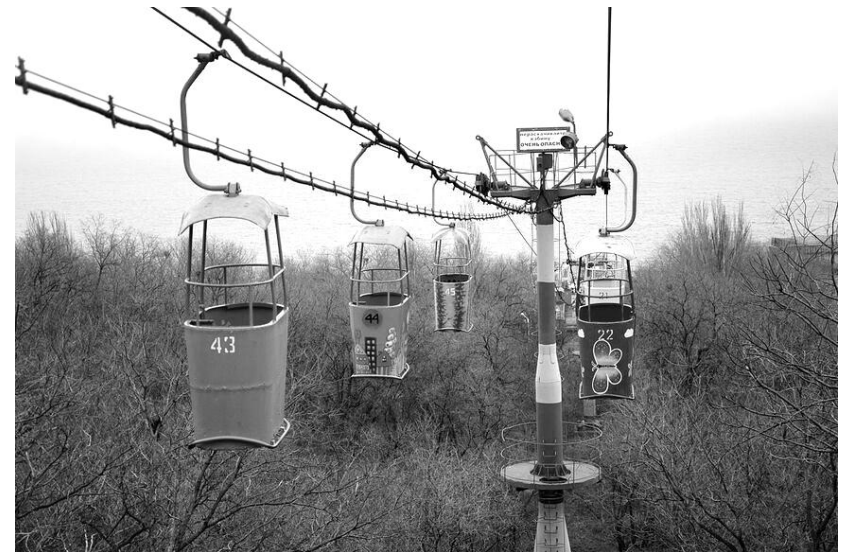

a)



b)

Fig. 5. The kinds of transport on Odessa hills:

$\mathrm{a}$ - The Odessa Cableway (1971) [14]; b - The fabulous tunnel in the sanatorium «Magnoliya»

(1979) [15]

In 1920s the most famous sanatorium of Odessa after Chkalov was opened (till 1938 - after Chubar and Semashko), it was founded on the territories of some former country house plots, and also the estate of Hrygoriy Marazli. On the sanatorium territory there were many interesting architectural buildings: 40-meter greenhouse (1889, arch. P. U. Kleyn) with the artificial grotto; "a lower country house" Marazli (was destroyed by the landslide); the country house of G.I. Shechter (is in the destroyed state); the country house of A.G. Ashkenazi, etc. But the most interesting engineering structure was the lift - the biggest in Odessa (Fig. 6) [16]. 


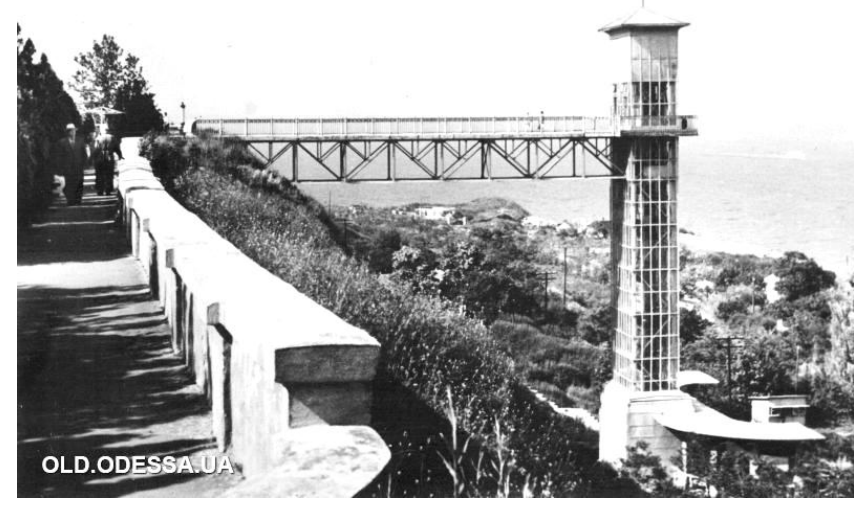

a)

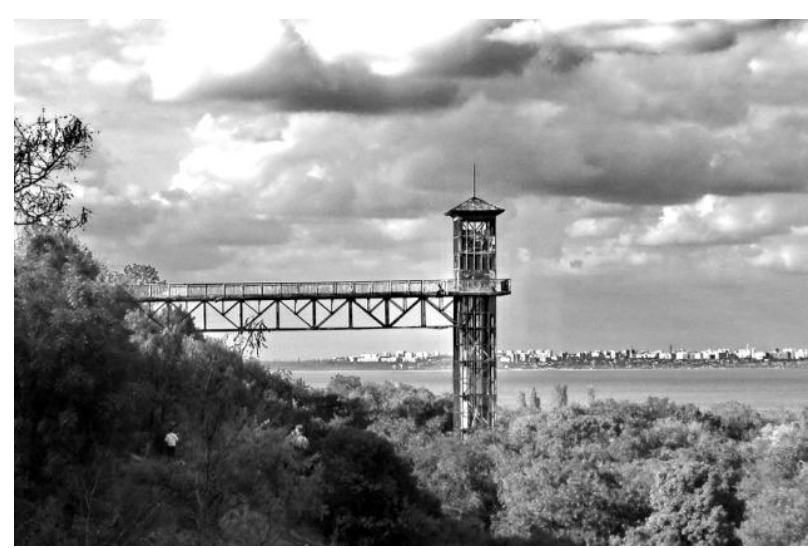

b)

Fig. 6. The Sanatorium after Chkalov:

a - "The lift". The photo of L. Shtern from the postcards set "Odessa", 1962 [17]; b - The Odessa hills. The lift (2000 years) [18]

The biggest lift was built in the post-war years and started working from the moment of the shore strengthening system as a breakwater, underground drainage and erecting slopes. It presented the 40-meter tower, to which the bridge from the sanatorium led, and was intended for the transportation of handicapped people to the beach. In 1963 the lift suffered very much in the time of the landslide - it sloped, but was restored in 1968 and worked till 1987, when its work was stopped, the lift decayed, and the landslide processes made it dangerous.

According to the general plan of 1989, the twin-brothers for the descend from the Nagorniy Boulevard had to appear by the lift. But the Boulevard wasn't built, the lift eventually destroyed and in the late 2000s it was disassembled. But in spite of this, yet 10 years more it remained a romantic place for people in love, and a favorite place for photographers and extreme people [18, 19].

The conclusions. In the result of the off-street transport system learning, the basic kinds of ground and underground transport, intended for people and auxiliary cargoes moving in the conditions of a complex relief, and the presence of water obstacles: conveyor, lifting, rail, cable, mono-rail, self-propelled were found. The advantages of the use of the suspended and mono-rail cableways were identified: functionality, economy, manufacturability, comfort and safety.

In the result of studying of the terrain peculiarity of the Odessa coast, it was founded the main recreational zone of the city are the slopes in height about 50 meters above the sea level, on which the parks are erected, and there is no traffic. Despite the fact that the Odessa hills don't have a complicated and steep relief, the overcome of rises and descends at a great distance is difficult for many population groups. As the result, the transport system in the conditions of a complicated relief, consisting of funiculars, a cableway, an escalator, tunnels, bridges and lifts was created. In the connection of the landslides, common on the Odessa hills, some transport complexes were destroyed by wars and disassembled (a monastic funicular, Chkalov lift). When the Odessa funicular, restored in 2005, the cableway and the fabulous tunnel became the attractions of the city that are used not only as the transport system, but also in the excursion purposes which makes the Odessa coast yet more attractive for the development of the regional and international tourism.

\section{References}

[1] A.M. Prokhorov. Vidy transporta. VikipediYA. Svobodnaya entsiklopediya. [Online]. Available: https://ru.wikipedia.org/wiki. Accessed on: December 29, 2020.

[2] Transportnyye sistemy i kompleksy ugol'nykh shakht. [Online]. Available: https://tst.nmu.org.ua/ua/Lekcia/Lec1.pdf. Accessed on: December 29, 2020.

[3] A.A. Korotkiy, A.V. Lagerev, B.CH. Meskhi, I.A. Lagerev, A.V. Panfilov, Razvitiye transportnoy infrastruktury krupnykh gorodov $i$ territoriy na osnove tekhnologii kanatnogo metro: monografiya. Rostov-na-Donu: Izdatel'stvo DGTU, 2017. 
[4] SuperRielt (2015). V Kitaye postroili same bol'shiye spiral'nyye eskalatory v mire (01.04.2015). FOTO. [Online]. Available: https://superrielt.ru/articles/6068/ Accessed on: December 29, 2020.

[5] Ronstruktor6 (2020). Gel'merskiy funikuler. FOTO. [Online]. Available: https://pikabu.ru/story/gelmerskiy_funikulyor_7297680. Accessed on: December 29, 2020.

[6] Orange Smile (2011). Kanatnaya doroga Complexo do Alemao, Braziliya. FOTO. [Online]. Available: https://www.orangesmile.com/extreme/ru/greatestcabletrams/complexo-do-alemao.htm\#object-gallery. Accessed on: December 29, 2020.

[7] A. Plekhanov (2018). Monorel's: dolgaya doroga k priznaniyu (21.09.2018). FOTO [Online]. Available: https://auto.mail.ru/article/70019-monorels_dolgaya_doroga_k_priznaniyu/ Accessed on: December 29, 2020.

[8] Odessa na kolesakh. Funikuler. FOTO. [Online]. Available: http://odessatrolley.com/Tram/Funiculair.htm. Accessed on: January 03, 2020.

[9] R. Aleksandrov. Odesskiy funikuler. VikipediYA. Svobodnaya entsiklopediya. [Online]. Available: https://ru.wikipedia.org/wiki. Accessed on: January 03, 2020.

[10] Víkna Odesa. Staraya Odessa v fotografiyakh. Funikuler (1944-1991). FOTO. [Online]. Available: http://viknaodessa.od.ua/old-photo/?funikuler-44-91. Accessed on: January 03, 2020.

[11] Benetako.com. Dostoprimechatel'nosti Odessy. FOTO. [Online]. Available: http://benetako.com/odessa/places.html. Accessed on: January 03, 2020.

[12] A. Vel'mozhko (2017). Malen'kiye zagadki staroy Odessy: istoriya monastyrskogo funikulera (FOTO) (8.02.2017). FOTO. [Online]. Available: https://uc.od.ua/news/urbanism/1187891. Accessed on: January 03, 2020.

[13] A. Dedyulina (2019). Odessa, kotoruyu ty ne znayesh': istoriya monastyrskogo funikulera (13.02.2019). [Online]. Available: https://od.vgorode.ua/news/obzory/388500odessa-kotoruui-ty-ne-znaesh-ystoryia-monastyrskoho-funykulera. Accessed on: January 03, 2020.

[14] M. Starostin (2020). Odesskaya kanatnaya doroga. (08.09.2020). FOTO. [Online]. Available: https://www.tourister.ru/world/europe/ukraine/city/odesa/cableways/28964 Accessed on: January 03, 2020.

[15] Taymer (2019). Znamenityy «Skazochnyy tonnel'» na Trassu zdorov'ya zarabotayet uzhe $\mathrm{v}$ etom godu. FOTO. [Online]. Available: https://timerodessa.net/news/skazochniy_tonnel_na_trassu_zdorovya_zarabotaet_uje_v_etom_godu_ 494.html. Accessed on: January 09, 2020.

[16] IGotoWorld.com. Skazochnyy tonnel', Odessa. [Online]. Available: https:// https://ua.igotoworld.com/ru/poi_object/78035_skazochnyy-tonnel-odessa.htm. Accessed on: January 09, 2020.

[17] Víkna Odesa. Staraya Odessa v fotografiyakh. 1962 g. Nabor otkrytok «Odessa». FOTO [Online]. Available: http://viknaodessa.od.ua/old-photo/?1962-nabor-otkrytok-odessa. Accessed on: January 09, 2020.

[18] A. Ignat'yeva (2016). Chkalovskiy sanatoriy v Odesse: arkhitektura, opolzni i znamenityy lift (FOTO) (21.11.2016). FOTO [Online]. Available: https://uc.od.ua/news/urbanism/1186248. Accessed on: January 09, 2020.

[19] D. Kornyshev (2014). Poteri Odessy: karaimskiy molitvennyy dom, muzey kosmonavtiki i samyy bol'shoy lift. [Online]. Available: https://dumskaya.net/news/poteri-odessykaraimskij-molitvennyj-dom-muzej-k-041375/ Accessed on: January 09, 2020. 


\title{
ВИВЧЕННЯ ОСОБЛИВОСТЕЙ ТРАНСПОРТНОЇ СИСТЕМИ ОДЕСЬКИХ СХИЛІВ. ОДЕСЬКІЙ ФУНІКУЛЕР
}

\author{
${ }^{1}$ Сторожук С.С., к.арх., доцент, \\ mesvet@ukr.net, ORCID: 0000-0001-8390-7190 \\ ${ }^{1}$ Дубініна Н. В., к.п.н., старший викладач, \\ naty.dubinina83@ukr.net, ORCID: 0000-0002-3250-9528 \\ ${ }^{1}$ Одеська державна академія будівництва та архітектури \\ вул. Дідріхсона 4, м. Одеса, 65029, Україна
}

\begin{abstract}
Анотація. У статті вивчена поза вулична транспортна система гірській місцевості. Були виявлені основні види підземного та наземного транспорту, призначеного для транспортування людей і допоміжних вантажів в умовах складного рельєфу або наявності водних перешкод: конвеєрний, ліфтовий, рейковий, канатний, монорельсовий, самохідний. Виявлено переваги використання підвісних та монорейкових канатних доріг: функціональність - застосування в межах великих міст-мегаполісів, так і в межах туристичних, рекреаційних та природних територій, не залежно від складності рельєфу; економічна перевага - інвестиційні та експлуатаційні витрати на будівництво канатних доріг в 2 рази менше, ніж при використанні автомобільного транспорту; комфортність та безпека - дозволяють розвантажити міські автомагістралі і забезпечують високий рівень комфорту; сучасні технології - нові види громадського пасажирського транспорту в урбанізованому середовищі - канатне метро.

Вивчено особливості Північно-Західного Причорномор'я - обривисті берега Одеської затоки - схили, які представляють собою похилі ділянки поверхні Землі, що сформувалися в результаті рельєфоутворюючих процесів, що протікають на суші та на дні Чорного моря.

Одеські схили є рекреаційною зоною і найпопулярнішим місцем для відпочинку місцевих жителів і гостей чорноморського узбережжя. На верхній кромці плато розташовані санаторії та будинки відпочинку, а на нижній - численні природні та штучні пляжі. Одеські схили висотою близько 50-и метрів над рівнем моря, розташовані вздовж чорноморського узбережжя в історичному ареалі міста, на яких розбиті парки і відсутній транспортний рух. Незважаючи на те, що Одеські схили не володіють складним і крутим рельєфом подолання підйомів та спусків на великій відстані є скрутним для багатьох груп населення. В результаті чого на схилах була створена транспортна система в умовах складного рельєфу, що складається з фунікулерів, канатної дороги, ескалатора, тунелів, мостів і ліфтів.

У зв'язку зі зсувами, поширеними на Одеських схилах, війнами та революціями деякі транспортні комплекси були зруйновані та демонтовані (монастирський фунікулер, Чкалівський ліфт). У той час як Одеський фунікулер, відновлений в 2005 році, Канатна дорога і казковий тунель стали визначними пам'ятками Одеси, які використовуються не тільки як транспортна система, але і в екскурсійних цілях, що робить Одеське узбережжя ще більш привабливим для розвитку регіонального та міжнародного туризму.
\end{abstract}

Ключові слова: складний рельєф, транспортна система, Одеські схили, канатні дороги, фунікулер. 


\title{
ИЗУЧЕНИЕ ОСОБЕННОСТЕЙ ТРАНСПОРТНОЙ СИСТЕМЫ ОДЕССКИХ СКЛОНОВ. ОДЕССКИЕ ФУНИКУЛЕРЫ
}

\author{
${ }^{1}$ Сторожук С. C., к. арх., доцент, \\ mesvet@ukr.net, ORCID: 0000-0001-8390-7190, \\ ${ }^{1}$ Дубинина Н. В., к.п.н., старший преподаватель, \\ naty.dubinina83@ukr.net, ORCID: 0000-0002-3250-9528, \\ ${ }^{1}$ Одесская государственная академия строительства и архитектуры \\ ул. Дидрихсона 4, г. Одесса, 65029, Украина
}

\begin{abstract}
Аннотация. В статье изучена внеуличная транспортная система горной местности. Были выявлены основные виды подземного и наземного транспорта, предназначенного для транспортирования людей и вспомогательных грузов в условиях сложного рельефа или наличия водных преград: конвейерный, лифтовой, рельсовый, канатный, монорельсовый, самоходный. Выявлены преимущества использования подвесных и монорельсовых канатных дорог: функциональность - применение в пределах крупных городов-мегаполисов, так и в пределах туристических, рекреационных и природных территорий, не зависимо от сложности рельефа; экономическое преимущество - инвестиционные и эксплуатационные расходы на строительство канатных дорог в 2 раза меньше, чем при использовании автомобильного транспорта; комфортность и безопасность - позволяют разгрузить городские автомагистрали и обеспечивают высокий уровень комфорта; современные технологии - новые виды общественного пассажирского транспорта в урбанизированной среде - канатное метро.
\end{abstract}

Изучены особенности Северо-Западного Причерноморья - обрывистые берега Одесского залива - склоны, которые представляют собой наклонные участки поверхности Земли, сформировавшиеся в результате рельефообразующих процессов, протекающих на суше и на дне Черного моря. Одесские склоны являются рекреационной зоной и самыми популярными местами для отдыха местных жителей и гостей черноморского побережья. На верхней кромке плато расположены санатории и дома отдыха, а на нижней многочисленные естественные и искусственные пляжи.

Одесские склоны высотой около 50-и метров над уровнем моря, расположены вдоль черноморского побережья в историческом ареале города, на которых разбиты парки и отсутствует транспортное движение. Несмотря на то, что Одесские склоны не обладают сложным и крутым рельефом преодоление подъёмов и спусков на большом протяжении является затруднительным для многих групп населения. В результате чего на склонах была создана транспортная система в условиях сложного рельефа, состоящая из фуникулеров, канатной дороги, эскалатора, тоннелей, мостов и лифтов.

В связи с оползнями, распространенными на Одесских склонах, войнами и революциями некоторые транспортные комплексы были разрушены и демонтированы (монастырский фуникулер, Чкаловский лифт). В то время как Одесский фуникулер, восстановленный в 2005 году, Канатная дорога и сказочный тоннель стали достопримечательностями Одессы, которые используются не только как транспортная система, но и в экскурсионных целях, что делает Одесское побережье еще более привлекательным для развития регионального и международного туризма.

Ключевые слова: сложный рельеф, транспортная система, Одесские склоны, канатные дороги, фуникулер.

Стаття надійшла до редакції 14.01.2021 